\title{
THE PROTEIN CONTENT OF THE EXTRACELLULAR FLUID IN NORMAL SUBJECTS AFTER VENOUS CONGESTION AND IN PATIENTS WITH CARDIAC FAILURE, ANOXEMIA, AND FEVER ${ }^{1}$
}

\author{
By EUGENE A. STEAD, JR., AND JAMES V. WARREN \\ (From the Medical Service of Grady Hospital and the Department of Medicine, Emory University \\ School of Medicine, Atlanta)
}

(Received for publication October 13, 1943)

No accurate measurements have ever been made of the protein content of the fluid which passes out of the vascular bed through the capillary wall. This filtrate, subject to change from resorption at the venous end of the capillary and lymph formation, makes up the extracellular fluid. In patients with massive edema, the fluid is markedly increased and pours forth when the tissues are cut. In the normal subject, this is not true because the extracellular fluid exists mainly in a jelly-like matrix. If many needles are inserted in the subcutaneous tissue of a normal subject, no detectable fluid will be found immediately in their lumina. If the needles are left in place for a period of hours, many of them will contain fluid which is yellow and has a high protein content. This fluid is almost pure plasma which has passed into the tissues because the capillaries have been injured locally by the foreign body. In other words, the capillary permeability to proteins has increased, and it is in this sense that the term will be used in this discussion. Variations in the speed of passage of various substances will not be considered. In most instances in clinical medicine, the factor of speed is relatively unimportant, for the changes leading to edema formation persist for many hours or days.

Though normal interstitial fluid cannot be obtained, it is possible to secure samples of the fluid which is formed in the legs of normal subjects as a result of elevated venous and capillary pressures. If it is assumed that this fluid contains at least as much and probably more protein than normal capillary filtrate, then determina-

\footnotetext{
1 The work described in this paper was done under a contract, recommended by the Committee on Medical Research, between the Office of Scientific Research and Development and the Emory University School of Medicine.
}

tion of the protein content of this fluid will set the extreme upper limit of the protein concentration in normal capillary filtrate. Furthermore, by producing edema in patients with fever or cardiac failure, it is possible to determine whether cardiac failure or fever alters the permeability of the capillaries of the leg to protein.

Though many useful data are obtained from the analyses of interstitial fluid, it is well to recognize at the onset that this method of study has definite limitations. The composition of the extracellular fluid is the result of many variables which in active life are constantly changing. A rise in capillary pressure changes the composition of the filtrate and tends to slow resorption. Motion increases lymph flow. The amount of filtrate varies with the blood flow. The extracellular fluid is thus constantly changing in composition and varies in different parts of the body. Because of these facts, it is not possible to define the characteristics of normal capillary filtrate or extracellular fluid except within wide limits. In addition to the factors noted above, capillaries in different portions of the body are variably permeable to protein. The data reported here for the subcutaneous tissues of the leg cannot be applied without further study to other areas of the body.

\section{METHOD}

The subjects remained at bed rest throughout the procedure. No attempt was made to control the temperature of the extremities, each individual using enough cover to remain comfortably warm. The venous congestion was induced at night so that the subjects were asleep during the greater portion of the time. A blood pressure cuff, $12 \mathrm{~cm}$. in width, was placed below the knee. A large reservoir with an opening in the bottom was attached to the blood pressure cuff and the entire system filled with water. The desired pressure in the cuff was obtained by raising or lowering the level of the water in the reservoir. Because the capacity of the reservoir was great in comparison to 
the volume of fluid in the cuff, movements of the subjects in bed caused little change in pressure.

At the end of 12 hours, the tourniquet was removed, and the leg elevated above the level of the heart for a few minutes. Six to eight No. 23 gauge needles were then inserted into the subcutaneous tissue and left in place for not longer than 5 minutes. The tissue pressure was increased by stretching the skin. The needles were removed and the fluid in them collected in glass capillary tubes. If the fluid was clear, it was examined under the microscope without removing it from the capillary tube. If the fluid was cloudy, or contained a large number of red blood cells, it was discarded. If there were only a few red cells, the specimen was accepted, because experience showed that the protein concentration of the fluid was not significantly affected by small numbers of cells. The total nitrogen content was determined by a modified microKjeldahl method with nesslerization and colorimetric determination with a photoelectric colorimeter (1). The nonprotein nitrogen of the blood serum was measured and subtracted from the total nitrogen of the edema fluid.

\section{NORMAL SUBJECTS}

Eleven acceptable samples of fluid were obtained from 7 normal subjects (Table I). The protein concentration ranged from 0.4 to 1.3 grams per cent, the average being 0.8 gram. In 4 instances, sufficient fluid was obtained to make 2 determinations, each one respresenting fluid from one or more needles. The protein concentration from the various areas differed by not more than 0.4 gram per cent.

TABLE I

Edema fluid obtained from normal subjects after application of cuff for 12 hours at $30 \mathrm{~mm}$. $\mathrm{Hg}$ pressure

\begin{tabular}{c|c|c|c}
\hline \multirow{2}{*}{ Subject } & Blood & \multicolumn{2}{|c}{ Edema fluid } \\
\cline { 2 - 4 } & Total protein & Obtained & Protein content \\
\cline { 2 - 4 } 1 & groms per 100 cc. & mgm. & grams per cent \\
& 6.5 & 5.1 & 1.0 \\
2 & & 2.9 & 0.8 \\
3 & 6.5 & 4.9 & 0.7 \\
& 6.9 & 8.6 & 0.7 \\
4 & & 27.2 & 0.9 \\
5 & 6.6 & 10.5 & 0.7 \\
& 6.7 & 5.6 & 0.6 \\
6 & & 5.3 & 0.4 \\
7 & 6.4 & 5.4 & 0.9 \\
& 6.4 & 2.7 & 1.3 \\
Average & 6.6 & 4.7 & 0.9 \\
\hline
\end{tabular}

The question immediately arose as to whether the local irritation from the needles caused the capillaries to become more permeable, thus raising the protein content of the edema fluid to a falsely high level. Therefore, studies were made on certain patients with comparably small amounts of edema, in whom equal difficulty was encountered in obtaining fluid. In this group, patients with cardiac failure, toxemia of pregnancy, and acute nephritis usually showed 0.1 to $\mathbf{0 . 2}$ gram per cent protein. It was concluded, therefore, that the method of collection did not account for the relatively high protein concentration of the edema fluid of the normal subjects.

It is impossible to say to what extent resorption of water from the tissues concentrated the protein in the edema fluid. As the edema appeared to form progressively over the 12-hour period and as the capillary pressure was quite high, it is fair to assume that resorption of water was much below normal.

Landis and his co-workers (2) studied the effect of venous congestion on the passage of fluid and protein through the human capillary wall. They calculated the relative amounts of water and protein entering the tissues of the congested part from the changes in the hematocrit reading and protein concentration of the blood draining from the part. It was concluded that, at a venous pressure of $80 \mathrm{~mm}$. $\mathrm{Hg}$, the capillary filtrate contained an average of 1.5 grams per cent of protein. At a venous pressure of $60 \mathrm{mg}$. $\mathrm{Hg}$, very little protein loss could be detected and the capillary filtrate contained an average of $\mathbf{0 . 3}$ gram per cent protein.

The question as to the amount of protein present in normal capillary filtrate is not answered by the above experiments. In many patients with cardiac failure, edema forms before there is a demonstrable change in venous and capillary pressures. The protein content of cardiac edema fluid should, therefore, give an indication of the amount of protein filtering through the capillaries at more nearly normal capillary pressures. If it could be shown that the capillaries of patients with cardiac failure are no more permeable to protein than those of normal subjects, the data obtained from cardiac edema fluid could be applied to the problem of the protein content of the normal capillary 
filtrate. With this in mind, patients with cardiac failure were studied.

\section{PATIENTS WITH CARDIAC FAILURE}

Edema fluid was obtained from 14 patients with cardiac failure. The protein content of fluid from the extremities varied from 0.03 to 0.6 gram per cent with an average of 0.24 gram per cent. These findings are similar to those reported in the literature (3).

In 14 patients, edema fluid was collected from 2 or more sites. The findings are recorded in Table II. In the majority of instances, the protein content of the edema fluid was approximately the same, regardless of the site. The

TABLE II

Observations on edema fluid from various sites in patients with cardiac failure

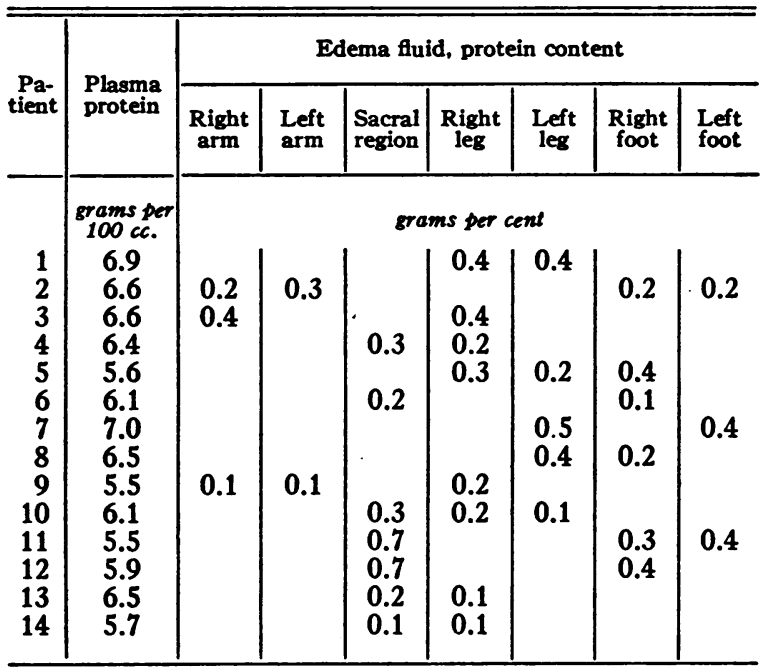

only exception was the sacral edema fluid, which tended to be somewhat higher than that from other subcutaneous tissue. In 3 patients, edema fluid was collected on admission to the hospital, and later again when the edema had been greatly reduced by bed rest and the administration of diuretics and digitalis. These results are given in Table III. The protein content of the edema fluid showed no significant increase, as the edema decreased. This is contrary to the findings in pleural fluid where there is a marked increase in protein concentration as the fluid is absorbed $(4,5)$. Our findings do not confirm the increase in the protein content of subcutaneous fluid with diuresis which has been reported (5).
TABLE III

Observations on edema fluid of patients with cardiac failure before and during compensation

\begin{tabular}{|c|c|c|c|}
\hline$\underset{\text { tient }}{\mathrm{Pa}-}$ & Date & $\begin{array}{c}\text { Edema } \\
\text { fluid, } \\
\text { protein } \\
\text { content }\end{array}$ & Remarks \\
\hline 1 & $\begin{array}{l}\text { September 29, } 1941 \\
\text { October 1, 1941 } \\
\text { April 22, 1942 }\end{array}$ & 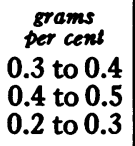 & $\begin{array}{l}\text { Much edema } \\
\text { Slight edema } \\
\text { Return of edema }\end{array}$ \\
\hline 2 & $\begin{array}{l}\text { October 1, } 1941 \\
\text { October 7, } 1941\end{array}$ & $\begin{array}{l}0.2 \text { to } 0.4 \\
0.3 \text { to } 0.4\end{array}$ & $\begin{array}{l}\text { Edema } \\
\text { Slight edema }\end{array}$ \\
\hline 3 & $\begin{array}{l}\text { December 30, } 1941 \\
\text { January 3, 1942 } \\
\text { January 9, } 1942\end{array}$ & $\begin{array}{l}0.3 \text { to } 0.4 \\
0.2 \\
0.3\end{array}$ & $\begin{array}{l}\text { Much edema } \\
\text { Less edema } \\
\text { Barely visible edema }\end{array}$ \\
\hline
\end{tabular}

The data recorded above indicate that, in general, the protein content of cardiac edema fluid is considerably lower than that obtained in normal subjects after venous congestion. The plasma protein levels were not significantly different in the two groups. It is probable, therefore, that the capillary filtrate in normal subjects is much lower at the usual capillary pressure than at the higher pressures used by us in producing edema fluid in normal subjects. Various authors have assumed that the capillaries in patients with heart failure are abnormally permeable to protein. If this were true, the capillary filtrate in normal subjects would contain less protein than that obtained from patients with congestive failure. To determine whether the capillaries of the leg in patients with heart failure were more permeable to protein than those of the normal subjects, the following experiments were performed.

The protein content of the edema fluid already present in the lower extremities was first determined. Digitalis and diuretics were given until the edema disappeared. The blood pressure cuff was then applied below the knee and inflated with a pressure of $30 \mathrm{~mm} . \mathrm{Hg}$, for 12 hours. At the end of this time, edema fluid was collected and the protein content determined. Three such experiments were performed. The protein content of the edema fluid before diuresis was $0.3,0.1$, and 0.4 gram per cent. The protein content of the edema fluid after 12 hours' congestion was $0.4,0.7$, and 0.9 gram per cent, respectively. These data indicate that the 
capillaries of the leg in patients with cardiac failure are no more permeable to protein than the vessels of normal subjects.

The above experiments suggest that the protein content of the capillary filtrate of patients with congestive heart failure does not exceed that of the normal subject. The protein content of normal capillary filtrate is probably considerably lower than that of cardiac edema fluid, for even in heart failure some resorption of fluid by the venous end of the capillary may take place. The finding that the edema fluid formed by venous congestion in normal subjects contained an average of 0.8 gram per cent of protein suggests that the protein leakage is increased as the capillary pressure rises. It is not possible to say whether the variations occurring from subject to subject in the protein content of the edema fluid result from differences in capillary permeability, in absorption of the fluid by the venous capillaries, or in lymph flow.

It has been noted previously that venous congestion produces edema more readily in patients with cardiac failure than in normal subjects (6). This observation has no bearing on capillary permeability. The capillaries are normally permeable to salt and water so that edema may form in the presence of normal capillaries. The more rapid accumulation of salt and water in the tissues of patients with congestive failure does not indicate that the capillaries are abnormally permeable.

\section{PATIENTS WITH ANOXEMIA}

Two patients with marked emphysema and arterial unsaturation were studied. The arterial blood was only 50 per cent and 60 per cent saturated with oxygen. The patients were cyanotic, confused, and uncooperative. The mental state improved with the administration of oxygen. They were orthopneic and developed pitting edema of the ankles. The protein content of the edema fluid was 0.2 and 0.1 gram per cent, respectively. The marked anoxemia had not increased the permeability of the capillaries of the lower extremities. It is well known that patients with marked arterial oxygen unsaturation from congenital heart disease do not develop edema unless their circulation fails. It is con- cluded that the oxygen unsaturation of the arterial blood must reach a level below that required to nourish the brain before capillary permeability in the leg is affected to such a degree that it is clinically significant. Death due to injury to the nerve cells occurs before the capillaries have been damaged sufficiently to leak protein. Tissue anoxia can result from very marked slowing of the blood flow, even in the presence of normal arterial oxygen saturation. Does this stagnant anoxia cause capillary damage and loss of plasma from the blood stream? This has been studied in the slow circulation caused by marked cardiac failure (7). These patients showed as profound an impairment in the circulation as that seen in patients with advanced shock. Measurements of the plasma volume, the hematocrit reading, the protein concentration of the plasma, and the protein content of edema fluid indicated that the majority of the capillaries of the body were not abnormally permeable to protein. Localized changes in capillary permeability in one organ could be overlooked by this method of study. In generalized stagnant anoxia, the cells of the brain and other organs become functionally incompetent before the capillaries have become abnormally permeable.

This does not mean that local anoxia cannot produce injury to a part with resulting increase in capillary permeability. Any form of injury to the capillaries, if severe enough, will increase their permeability to protein. In practice, marked local anoxia is associated with a deficient supply of the other constituents of the blood, and it is difficult to tell what portion of the cell damage is the result of anoxia alone.

\section{PATIENTS WITH FEVER AND INFECTION}

The effect of fever and infection on capillary permeability in the leg was studied. Edema in the leg was produced by a 12-hour period of venous congestion, with a tourniquet inflated to a pressure of $30 \mathrm{~mm}$. $\mathrm{Hg}$. In 5 patients, the protein content of this fluid ranged from 0.3 to 0.9 gram per cent, the average being 0.5 gram per cent (Table IV). This indicated that the capillaries in the leg were not made more permeable to protein as a result of fever and infection. 
TABLE IV

Edema fluid obtained from patients with fever after application of cuff for 12 hours at $30 \mathrm{~mm}$. $\mathrm{Hg}$ pressure

\begin{tabular}{ccc}
\hline \hline Patient & $\begin{array}{c}\text { Plasma, } \\
\text { total protein }\end{array}$ & $\begin{array}{c}\text { Edema. } \\
\text { total protein }\end{array}$ \\
\hline & grams per $100 \mathrm{cc}$. & grams per cent \\
1 & 6.7 & 0.3 \\
2 & 5.1 & 0.3 to 0.5 \\
3 & 5.2 & 0.3 \\
4 & 6.5 & 0.6 to 0.7 \\
5 & 6.2 & 0.9 \\
Average & 5.9 & 0.5 \\
\hline
\end{tabular}

The above conclusion is supported by our previous observations on the plasma volume changes in patients dying of acute infectious diseases (8). When the patients received an adequate fluid intake, there was no decrease in plasma volume and no fall in the plasma protein concentration. This is interpreted as showing that the infection had produced no generalized increase in capillary permeability. It does not mean that the capillaries are not abnormally permeable in local areas, for example in the lung in pneumonia. It does mean that the body is able to add new protein to the blood stream as rapidly as it is lost so that the circulation as a whole is not affected.

\section{SUMMARY AND CONCLUSIONS}

1. The filtrate from the capillaries of the skin and subcutaneous tissues normally contains some protein. On the average, it does not contain more than 0.24 gram per cent of protein. It probably contains much less.

2. Elevation of the venous pressure in the leg to a level equal to $30 \mathrm{~mm}$. $\mathrm{Hg}$ produces edema which contains from 0.4 to 1.3 grams per cent of protein, with an average of 0.8 gram per cent.
3. Cardiac failure does not make the capillaries of the leg more permeable to protein.

4. Generalized anoxemia, sufficient to cause impaired cerebral function, does not cause increased permeability of capillaries in the leg. Although local ischemia produces capillary damage and leakage of protein, generalized stagnant anoxia of a degree compatible with life does not make the capillaries of the leg more permeable to protein.

5. Fever and acute infectious disease cause no abnormal increase in permeability to protein in the capillaries of the leg.

\section{BIBLIOGRAPHY}

1. Schales, O., Ebert, R. V., and Stead, E. A., Jr., Capillary tube Kjeldahl method for determining protein content of 5 to 20 milligrams of tissue fluid. Proc. Soc. Exper. Biol. and Med., 1942, 49, 1.

2. Landis, E. M., Jonas, L., Angevine, M., and Erb, W., The passage of fluid and protein through the human capillary wall during venous congestion. J. Clin. Invest., 1932, 11, 717.

3. Bramkamp, R. G., The protein content of subcutaneous edema fluid in heart disease. J. Clin. Invest., 1935, 14, 34.

4. Iversen, P., and Johansen, A. H., Pathogenese und Resorption von Trans- und Exsudaten in der Pleura. Klin. Wchnschr., 1929, 8, 1311.

5. Gilligan, D. R., Volk, M. C., and Altschule, M. D., The diffusibility of plasma calcium following parathormone administration. Comparison of the calcium, phosphate, and protein concentrations of serum and edema fluids. J. Biol. Chem., 1933, 103, 745.

6. Smirk, F. H., Observations on the causes of oedema in congestive heart failure. Clin. Sc., 1936, 2, 317.

7. Stead, E. A., Jr., and Ebert, R. V., Shock syndrome produced by failure of the heart. Arch. Int. Med., 1942, 69, 369.

8. Ebert, R. V., and Stead, E. A., Jr., Circulatory failure in acute infections. J. Clin. Invest., 1941, 20, 671. 